\title{
Net absorption from portal-drained viscera of nitrogenous compounds by beef heifers fed on diets differing in protein solubility or degradability in the rumen
}

\author{
BY GERALD B. HUNTINGTON \\ United States Department of Agriculture, Ruminant Nutrition Laboratory, Room 124, \\ Building 200, BARC-East, Beltsville, MD 20705, USA
}

\author{
(Received 17 February 1986 - Accepted 19 August 1986)
}

\begin{abstract}
1. The objective of the present study was to evaluate effects of in vitro rumen solubility or degradability of dietary protein on net absorption of nitrogenous compounds from portal-drained viscera of beef heifers.

2. Four protein sources, casein, soya-bean meal, maize-gluten meal and blood meal provided about two-thirds of total dietary nitrogen in semi-purified diets given to four beef heifers in a $4 \times 4$ Latin square design.

3. Although in vitro degradability of dietary $\mathrm{N}$ ranged from 842 (casein) to 310 (blood meal) $\mathrm{g} / \mathrm{kg}$ total dietary $\mathrm{N}$, net absorption of ammonia- $\mathrm{N}$ or $\alpha$-amino- $\mathrm{N}$ was not significantly different $(P>0 \cdot 10)$ among diets. However, net absorption of $\mathrm{NH}_{3}-\mathrm{N}$ tended to decrease and net absorption of $\alpha$-amino- $\mathrm{N}$ tended to increase as intake of in vitro undegradable $\mathbf{N}$ increased. Net transfer of urea- $\mathrm{N}$ from plasma to portal-drained viscera was greater $(P<0 \cdot 10)$ when heifers were fed on soya-bean meal than when fed on maize-gluten meal or blood meal.

4. The findings show with all diets that the non-protein-nitrogenous compounds, $\mathbf{N H}_{3}$ and urea, played a substantial role in absorption and transfer of $\mathrm{N}$. Overall, net absorption of $\mathrm{NH}_{3}-\mathrm{N}$ was $61 \%$ of net absorption of $\alpha$-amino- $\mathrm{N}$, and transfer of urea- $\mathrm{N}$ from plasma to portal-drained viscera was $80 \%$ of net absorption of $\alpha$-amino- $\mathrm{N}$.
\end{abstract}

Amino acids and ammonia derived from rumen degradation of dietary protein can be absorbed from the portal-drained viscera (PDV) or used for rumen microbial protein synthesis. Similarly, urea transferred from blood to PDV can be used for microbial protein synthesis, or reabsorbed as $\mathrm{NH}_{3}$. The composition of nitrogenous compounds reaching the abomasum is affected by the rate and extent of rumen degradation of proteins which usually is characterized by shifts in proportions of $\mathrm{NH}_{3}$-nitrogen and non- $\mathrm{NH}_{3}-\mathrm{N}$ in abomasal contents ((US) National Research Council, 1985). Dietary and microbial sources of nitrogenous compounds are combined with endogenous sources to provide a mixture of amino acids, $\mathrm{NH}_{3}-\mathrm{N}$, nucleic acids and other nitrogenous compounds for absorption from the small intestine ((US) National Research Council, 1985).

Potential and theoretical benefits of providing rumen-undegraded dietary amino acids to the small intestine have been described (Chalupa, 1975). However, there is little evidence that alteration of rumen solubility of dietary protein affects net amino acid absorption. Rates of intestinal disappearance and net portal appearance of amino acids are not the same (Tagari \& Bergman, 1978) and there is a net loss of some amino acids from plasma to PDV (Sniffen \& Jacobson, 1975; Tagari \& Bergman, 1978; Prior et al. 1981). There are small but discernible responses in net amino acid or $\mathrm{NH}_{3}-\mathrm{N}$ absorption with changes in stage of maturity (and level of protein intake) of lucerne (Medicago sativa) fed as the only dietary component (Sniffen \& Jacobson, 1975), level of lucerne-protein intake (Tagari \& Bergman, 1978 ), level of intake of lucerne or orchard-grass (Dactylis glomerata) silage (Huntington et al. 1985), or level of intake of a high-concentrate diet (Huntington \& Prior, 1983, 1985). Recent comparison of lucerne and orchard-grass silages given to Holstein steers showed that the only difference between silages was greater net absorption of $\mathrm{NH}_{3}-\mathrm{N}$ with lucerne; net absorption of amino acids or $\alpha$-amino- $N$, or transfer of urea-N (UN), was similar between silages (Huntington et al. 1985). 
Table 1. Dry matter composition of diets*

\begin{tabular}{|c|c|c|c|c|}
\hline \multirow[b]{2}{*}{ Ingredients ( $\mathrm{g} / \mathrm{kg}$ dry matter) } & \multicolumn{4}{|c|}{ Protein source } \\
\hline & $\mathrm{C}$ & SBM & MGM & BM \\
\hline Maize starch & 492 & 438 & 458 & 488 \\
\hline Cottonseed hulls & 300 & 300 & 300 & 300 \\
\hline Ground lucerne (Medicago sativa) hay & 100 & 100 & 100 & 100 \\
\hline Sodium caseinate $(C)$ & 86 & $\ldots$ & - & - \\
\hline Soya-bean meal (SBM) & - & 143 & - & - \\
\hline Maize-gluten meal (MGM) & - & - & 130 & - \\
\hline Blood meal (BM) & - & - & - & 90 \\
\hline Urea & 5 & 5 & 5 & 5 \\
\hline Dicalcium phosphate & 12 & 9 & 9 & 9 \\
\hline Vitamins $A$ and $D \dagger$ & + & + & + & + \\
\hline
\end{tabular}

* Formulated to contain $120 \mathrm{~g}$ crude protein (nitrogen $\times 6.25$ ) and $12.58 \mathrm{MJ}$ metabolizable energy $/ \mathrm{kg}$ matter.

$\uparrow$ Added to provide $400 \mathrm{mg}$ vitamin $\mathrm{A}$ and $20 \mathrm{mg}$ vitamin $\mathrm{D} / \mathrm{kg}$ dry matter.

The objective of the present experiment was to determine the effect of in vitro solubility or degradability of dietary protein on net absorption of $\mathrm{NH}_{3}-\mathrm{N}, \mathrm{UN}$ and $\alpha$-amino- $\mathrm{N}$ by beef heifers.

\section{MATERIALS AND METHODS}

Four Hereford $\times$ Angus heifers (mean live weight $424 \mathrm{~kg}$ ), with catheters in the portal vein, mesenteric vein and iliac artery, were used in a $4 \times 4$ Latin square design that included semi-purified diets containing casein (C), soya-bean meal (SBM), maize-gluten meal (MGM) or blood meal (BM) as sources of protein (Table 1). Semi-purified diets were used to place as much emphasis as possible on the protein sources, yet retain a diet of reasonable acceptability to the heifers. Diets contained chopped lucerne hay and urea in an effort to provide adequate fermentable substrate for microbial growth in the rumen. Diets were pelleted and formulated to contain equal amounts of crude protein $(\mathrm{N} \times 6.25)$, metabolizable energy, calcium and phosphorus on a per $\mathrm{kg}$ dry matter (DM) basis. Surgical preparation and housing of the heifers have been described (Huntington \& Prior, 1983). Heifers were fed on each diet for 2 weeks between measurements of portal blood flow and net absorption from PDV at hourly intervals for $8 \mathrm{~h}$. Diets were fed in three equal portions at $8 \mathrm{~h}$ intervals $5 \mathrm{~d}$ before and during measurements. Thus, measurements encompassed one of the three daily intervals among feedings.

Portal blood and plasma flow were determined by dilution of $p$-aminohippurate infused into the mesenteric vein (Huntington, 1982). About $30 \mathrm{ml}$ blood were collected hourly from catheters in the portal vein and iliac artery. Plasma from each source was stored frozen until concentrations of $\mathrm{NH}_{3}-\mathrm{N}, \mathrm{UN}$ and $\alpha$-amino- $\mathrm{N}$ were determined by automated procedures (Technicon Industrial Systems, Tarrytown, New York, USA); $\mathrm{NH}_{3}-\mathrm{N}$ was determined by the hypochlorite method (Technicon Industrial method no. 337-74T), UN by the acetylmonoxime method (Technicon Industrial method no. 339-01) and $\alpha$-amino-N by the ninhydrin method of Broderick \& Kang (1980) modified to include dialysis of plasma.

Feed samples were composited weekly during the experiment and prepared for analysis by grinding through a $1 \mathrm{~mm}$ screen. DM was determined by drying samples at $100^{\circ}$ for $24 \mathrm{~h}$. Total $\mathbf{N}$ was determined by Kjeldahl procedures. In vitro rumen solubility of $\mathbf{N}$ in the total diet was determined in modified Burrough's buffer as described by Waldo \& Goering 
Table 2. Daily intake of nitrogen and dry matter $(D M)$ by heifers fed on diets containing four different protein sources

\begin{tabular}{|c|c|c|c|c|c|}
\hline \multirow[b]{2}{*}{ Item } & \multicolumn{4}{|c|}{ Protein source } & \multirow[b]{2}{*}{ SEM } \\
\hline & $\mathrm{C}$ & SBM & MGM & BM & \\
\hline Dietary N (g/kg DM) & $20 \cdot 7$ & $21 \cdot 7$ & $22 \cdot 0$ & $22 \cdot 0$ & $0 \cdot 2$ \\
\hline $\mathrm{DM}$ intake $(\mathrm{kg} / \mathrm{d})$ & 5.57 & 5.75 & $5 \cdot 76$ & $5 \cdot 72$ & 0.04 \\
\hline $\mathrm{N}$ intake $(\mathrm{g} / \mathrm{d})^{*}$ & 115 & 125 & 125 & 126 & 2 \\
\hline Insoluble $\mathrm{N}$ intake $(\mathrm{g} / \mathrm{d})^{*} \dagger$ & 30 & 96 & 104 & 102 & 2 \\
\hline Undegradable $\mathrm{N}$ intake $(\mathrm{g} / \mathrm{d})^{*} \neq \S$ & 18 & 28 & 68 & 87 & 1 \\
\hline
\end{tabular}

C, casein; SBM, soya-bean meal; MGM, maize-gluten meal; BM, blood meal. Orthogonal contrasts of treatments: ${ }^{*} \mathrm{C} v$. others $(P<0.05) ; \nmid \mathrm{SBM} v$. MGM + BM $(P<0.10) ; \ddagger$ SBM $v$. MGM + BM $(P<0.05)$; $\S$ MGM $v$. BM $(P<0 \cdot 05)$.

(1979), and in vitro rumen degradability of $\mathrm{N}$ in the total diet was determined as described by Poos-Floyd et al. (1985).

Values were analysed statistically with the means and general linear models procedures of Statistical Analysis Systems (1979). Means were generated for each heifer-diet cell and analysed in a model that included effects due to heifers, diets and periods tested $v$. residual mean squares. Orthogonal contrasts of diets were selected before the experiment began to compare diets of greater in vitro solubility or degradability with diets containing progressively lesser amounts of those fractions. Orthogonal contrasts included: C compared with all others; SBM compared with MGM and BM; and MGM compared with BM. Effects of sampling time were analysed in a split-plot model where main effects were heifer, diet and period, and split-plot effects were sampling time and interactions of sampling time with main effects. Effect of sampling time was tested against the sampling time $\times$ heifer interaction; other split-plot effects were tested $v$. residual mean squares.

RESULTS

$\mathrm{N}$ content of the C-containing diet was slightly less than that of other diets (Table 2) because the factor for conversion of $\mathrm{N}$ to crude protein for $\mathrm{C}(6 \cdot 38)$ was different than that for other protein sources $(6 \cdot 25)$. Also, daily DM intake for $5 \mathrm{~d}$ before and including sampling day was less $(P<0.05)$ for heifers fed on the $\mathrm{C}$-containing diet than that for other diets; hence, daily $\mathrm{N}$ intake was $10-12 \mathrm{~g}$ less $(P<0.05)$ for heifers fed on the $\mathrm{C}$-containing diet compared with other diets (Table 2 ). In vitro $\mathrm{N}$ insolubility $(\mathrm{g} / \mathrm{kg}$ total dietary $\mathrm{N}$ ) was $262,767,819$ and 810 for diets containing C, SBM, MGM or BM respectively. Corresponding in vitro undegradability was $158,227,536$ and 689 , indicating that while insolubility of $N$ in the SBM-containing diet was more similar to diets containing MGM or BM than that containing C, undegradability of the diet containing SBM was more similar to the diet containing $\mathrm{C}$ than those containing MGM or BM. Differences among diets in solubility or degradability of $\mathrm{N}$ were reflected in differences in daily intake of those $\mathrm{N}$ fractions (Table 2).

Concentrations of UN and $\alpha$-amino- $\mathrm{N}$ in arterial plasma (Table 3) were similar among diets, but concentrations of $\mathrm{NH}_{3}-\mathrm{N}$ were slightly lower $(P<0 \cdot 10)$ when heifers were fed on SBM than when fed on MGM or BM, and slightly lower $(P<0 \cdot 10)$ when heifers were fed on MGM than when fed on BM. Conversely, differences in portal-arterial (P-A) concentration for $\mathrm{NH}_{3}-\mathrm{N}$ were similar among diets, but $\mathrm{P}-\mathrm{A}$ differences for $\alpha$-amino- $\mathrm{N}$ were 
Table 3. Plasma concentrations and net absorption from portal-drained viscera of nitrogenous compounds, and portal plasma flow of beef heifers fed on diets containing four different protein sources

\begin{tabular}{|c|c|c|c|c|c|}
\hline & \multicolumn{4}{|c|}{ Protein source } & \multirow[b]{2}{*}{ SEM } \\
\hline & $\mathrm{C}$ & SBM & MGM & $\mathrm{BM}$ & \\
\hline \multicolumn{6}{|l|}{ Arterial plasma (mM) } \\
\hline Urea-nitrogen & $7 \cdot 32$ & $8 \cdot 64$ & $7 \cdot 19$ & $6 \cdot 47$ & $1 \cdot 02$ \\
\hline Ammonia- $\mathrm{N}_{+}^{+* *}$ & 0.119 & $0 \cdot 107$ & $0 \cdot 110$ & $0 \cdot 123$ & 0.004 \\
\hline$\alpha$-amino-N & 2.02 & $2 \cdot 20$ & $2 \cdot 17$ & $2 \cdot 27$ & $0 \cdot 14$ \\
\hline \multicolumn{6}{|l|}{ Portal-arterial difference (mM) } \\
\hline Urea-N\$ & $-0 \cdot 22$ & $-0 \cdot 31$ & $-0 \cdot 25$ & $-0 \cdot 26$ & 0.02 \\
\hline Ammonia-N & 0.199 & 0.225 & 0.168 & 0.190 & 0.012 \\
\hline$\alpha$-amino-N $\dagger$ & 0.25 & $0 \cdot 39$ & 0.32 & 0.41 & 0.05 \\
\hline \multicolumn{6}{|l|}{ Net absorption $(\mathrm{mmol} / \mathrm{h})$} \\
\hline Urea-N+ & -125 & -157 & -135 & -120 & 12 \\
\hline Ammonia-N & 114 & 116 & 90 & 83 & 16 \\
\hline$\alpha$-Amino-N & 139 & 189 & 170 & 168 & 29 \\
\hline Portal plasma flow $(1 / h)^{* * * * *}$ & 570 & 520 & 536 & 454 & 24 \\
\hline
\end{tabular}

C, casein; SBM, soya-bean meal; MGM, maize-gluten meal; BM, blood meal.

Orthogonal contrasts of treatments: $\nmid \mathrm{C} v$. others $(P<0 \cdot 10) ;{ }^{*} \mathrm{C} v$. others $(P<0.05) ; \ddagger \mathrm{SBM} v . \mathrm{MGM}+\mathrm{BM}$ $(P<0 \cdot 10) ;{ }^{* *} \mathrm{MGM} v$. BM $(P<0 \cdot 10) ; * * *$ MGM $v . \mathrm{BM}(P<0 \cdot 05)$.

lower $(P<0 \cdot 10)$ when heifers were fed on diet $\mathrm{C}$ than when fed on other diets (Table 3 ). Differences in P-A concentration of UN were negative in all diets indicating net transfer of UN from plasma to PDV (Table 3$)$; this P-A difference tended to be greater $(P<0 \cdot 10)$ when heifers were fed on SBM than when fed on MGM or BM.

There were no differences $(P>0 \cdot 10)$ among diets in net absorption ( $\mathrm{P}-\mathrm{A}$ concentration difference $\times$ plasma flow) of $\mathrm{NH}_{3}-\mathrm{N}$ or $\alpha$-amino- $\mathrm{N}$, but transfer of $\mathrm{UN}$ from plasma to PDV was greater $(P<0 \cdot 10)$ when heifers were fed on SBM than when fed on MGM or BM. Except for the diet containing SBM, trends toward decreased net absorption of $\mathrm{NH}_{3}-\mathrm{N}$ and increased net absorption to $\alpha$-amino-N (Table 3 ) with increased intake of in vitro insoluble or undegradable $\mathrm{N}$ (Table 2) counterbalanced, so the sum of net absorption of $\mathrm{NH}_{3}-\mathrm{N}$ and $\alpha$-amino-N was $253,305,260$ and $251 \mathrm{mmol} / \mathrm{h}$ (SE 35) for diets containing C, SBM, MGM or BM respectively, and did not differ $(P>0.85)$ among protein sources. Portal plasma flow-rate was faster $(P<0.05)$ when the heifers were fed on the diet containing $\mathrm{C}$ than when fed on the other diets, and faster $(P<0.05)$ when fed on MGM than BM (Table 3).

There were differences $(P<0.05)$ among sampling times for concentrations in arterial and portal plasma of $\mathrm{NH}_{3}-\mathrm{N}, \mathrm{UN}$ and $\alpha$-amino-N, and for net absorption of $\mathrm{NH}_{3}-\mathrm{N}$. These differences were highest around feeding time followed by a gradual decline towards the next feeding time. There was a sampling time $\times$ diet interaction $(P<0.01)$ for $\mathrm{P}-\mathrm{A}$ difference of $\alpha$-amino-N; the $\mathrm{P}-\mathrm{A}$ difference when heifers were fed on $\mathrm{C}$ gradually decreased after feeding, was fairly constant when fed on SBM and BM after feeding, and decreased when fed on MGM (until $5 \mathrm{~h}$ after feeding), then increased until the next feeding time.

\section{DISCUSSION}

Lack of differences $(P>0 \cdot 10)$ in net absorption of nitrogenous compounds when in vitro insoluble- $\mathrm{N}$ intake ranged from 26 to $82 \%$ or in vitro undegradable- $\mathrm{N}$ intake ranged from 16 to $69 \%$ of total $\mathrm{N}$ intake (Table 2), suggests that complex interrelations existed among 
digestion, metabolism by gut microbes and absorption of nitrogenous and non-nitrogenous (carbohydrate) portions of the diets. A review of ruminant $\mathrm{N}$ usage ((US) National Research Council, 1985) describes these interrelations and points out the need for rumen-available $\mathrm{N}$ in diets containing readily fermentable carbohydrates, such as those given in the present study (Table 1), to sustain or promote microbial growth in the rumen. The presence of dietary urea and similarity of carbohydrate sources among diets were intended at least to equalize the contribution of microbial $\mathbf{N}$ to sources of $\mathrm{N}$ available for absorption. Similarity in digestion and absorption dynamics was supported by the absence of sampling time $x$ diet interactions for net absorption rates. Complications or biases due to the semi-purified nature of the diets cannot be ruled out, but net absorption rates in the present study were not unusual or extreme when compared with rates from other studies in which diets based on ordinary feedstuffs were given to cattle or sheep (Huntington, 1986). However, daily DM intake in the present study $(13 \mathrm{~g} / \mathrm{kg}$ live weight) was less than one might expect with ordinary diets fed ad lib., which would tend to minimize differences in in vivo degradability among protein sources. Average net absorption rates (Table 3) show that net absorptions of $\mathrm{NH}_{3}-\mathrm{N}$ when $\mathrm{C}$ was fed were 98,127 and $137 \%$ of net absorption when SBM, MGM or BM was fed respectively. Net absorptions of $\alpha$-amino-N when $\mathrm{C}$ was fed were 75,82 and $84 \%$ of net absorption when SBM, MGM or BM was fed respectively. It is possible that daily feed intake, limitation of numbers of heifers $(n 4)$ and concomitant statistical calculations, precluded statistical confirmation of increased absorption of $\alpha$-amino- $\mathrm{N}$ in response to increased in vitro insolubility or undegradability of dietary $\mathrm{N}$.

The contribution of microbial $\mathrm{N}$ sources to amounts and forms of $\mathrm{N}$ available for absorption was not characterized in the present study. However, studies of $\mathrm{N}$ digestion and absorption based on rates of passage of digesta and disappearance in situ or in vitro ('absorption' being that which disappeared) may not have accounted adequately for amounts of $\mathrm{NH}_{3}-\mathrm{N}$ absorbed or $\mathrm{UN}$ transferred from plasma to the lumen of the gut. For example, net absorption from PDV, as measured in the present study, accounts for the net effect of endogenous secretion of $\mathrm{N}$ from the pancreas or sloughing of tissue from PDV, which studies based on disappearance techniques do not. Extensive catabolism of amino acids during absorption (Tagari \& Bergman, 1978) and substantial post-rumen absorption of $\mathrm{NH}_{3}-\mathrm{N}$ or transfer of UN (Huntington, 1986; Huntington \& Reynolds, 1986) would contribute to an underestimation of the role of these non-protein, nitrogenous compounds to overall $\mathrm{N}$ metabolism of ruminants as measured by techniques based on disappearance. Net absorption of $\mathrm{NH}_{3}-\mathrm{N}$ ranges from 40 to $650 \%$ of net absorption of $\alpha$-amino- $\mathrm{N}$ in cattle and sheep, and net transfer of $\mathrm{UN}$ ranges from 10 to $42 \%$ of $\mathrm{N}$ intake (Huntington, 1986). In the present study, net absorption of $\mathrm{NH}_{3}-\mathrm{N}$ was $61 \%$ of net absorption of $\alpha$-amino- $\mathrm{N}$ and net transfer of UN was $80 \%$ of net absorption of $\alpha$-amino- $\mathrm{N}$.

The role of solubility or degradability of dietary $\mathbf{N}$ in the rumen in overall protein or energy metabolism is not clear; apparent digestibility of $\mathrm{N}$ may (Prange et al. 1984) or may not (Stern et al. 1978; Waller et al. 1980; Stock et al. 1981) vary when protein sources of different solubilities or degradabilities are fed, but rate of live-weight gain and efficiency of feed conversion, particularly in growing cattle, is affected by varying protein sourcesolubility (Spears et al. 1980; Waller et al. 1980; Loerch \& Berger, 1981; Stock et al. 1981). These results and the inability to show substantial responses to protein sources in the profile of amino acids in digesta entering the duodenum (Steinhour et al. 1982; Merchen \& Satter, 1983; Prange et al. 1984) or absorbed by PDV (Prior et al. 1981; Huntington et al. 1985) indicate the 'buffering effect' of microbial $\mathrm{N}$ and endogenous $\mathrm{N}$ on the overall pattern of protein digestion and amino acid absorption, and suggest differences in gain and feed efficiency are not attributable entirely to differences in rates or proportions of amino acids absorbed from the small intestine.

Reasons for differences among diets in plasma flow-rate through PDV (Table 3) are not 
clear; ostensibly, part of the difference was due to in vitro solubility or degradability of dietary protein, because decreased plasma flow-rate generally followed the pattern of insoluble- $\mathrm{N}$ intake, being fastest with the most soluble or degradable protein source $(\mathrm{C})$, and slowest with the most undegradable protein source (BM; Table 2). However, the SBM-containing diet was anomalous, or deviated from the correlation between solubilitydegradability of protein sources and plasma flow-rate. Similarly, correlations of trends or responses in arterial concentrations or $\mathrm{P}-\mathrm{A}$ differences of $\mathrm{UN}, \mathrm{NH}_{3}-\mathrm{N}$ or $\alpha$-amino- $\mathrm{N}$ with solubility-degradability of protein source were anomalous for the SBM-containing diet (Table 3), again suggesting complex interrelations among digestive and metabolic functions discussed previously. Mathematically, the effect was to diminish net absorption rates of $\alpha$-amino- $\mathrm{N}$ and transfer rates of $\mathrm{UN}$, in spite of the fact that $\mathrm{P}$-A differences of those compounds increased as $\mathrm{N}$ solubility or degradability decreased (Table 3 ). The findings point out a risk of misinterpretation of plasma concentrations or concentration differences without consideration of blood or plasma flow-rates.

In summary, two main points can be derived from the results presented. First, wide differences in in vitro solubility or degradability of dietary $\mathrm{N}$ were reflected in trends in net absorption of $\mathrm{NH}_{3}-\mathrm{N}$ and $\alpha$-amino- $\mathrm{N}$, but rates or patterns of net absorption of $\mathrm{NH}_{3}-\mathrm{N}$ or $\alpha$-amino-N, or net transfer of UN from plasma to PDV, were not statistically different among diets. Second, even when the diet contained predominantly in vitro insoluble or undegradable protein, there was substantial absorption of $\mathrm{NH}_{3}-\mathrm{N}$ and transfer of $\mathrm{UN}$, indicating a need to consider non-protein- $\mathrm{N}$ compounds when evaluating metabolism of dietary protein by ruminants.

The author gratefully acknowledges the assistance of animal operations personnel in surgical preparation, care and feeding of the heifers; and Ms J. Whitt and Ms E. Zetina for their able laboratory work. The author thanks Dr Robert Britton for analysis of in vitro $\mathrm{N}$ degradability in the diets.

\section{REFERENCES}

Broderick, G. A. \& Kang, J. H. (1980). Journal of Dairy Science 63, 64-75.

Chalupa, W. (1975). Journal of Dairy Science 58, 1198-1218.

Huntington, G. B. (1982). Journal of Dairy Science 65, 1155-1162.

Huntington, G. B. (1986). Federation Proceedings 45, 2272-2276.

Huntington, G. B. \& Prior, R. L. (1983). Journal of Nutrition 113, 2280-2288.

Huntington, G. B. \& Prior, R. L. (1985). Journal of Animal Science 60, 1491-1499.

Huntington, G. B. \& Reynolds, C. K. (1986). Federation Proceedings 45, 606 Abstr.

Huntington, G., Varga, G., Waldo, D. \& Glenn, B. (1985). Federation Proceedings 44, 760 Abstr.

Loerch, S. C. \& Berger, L. L. (1981). Journal of Animal Science 53, 1198-1203.

Merchen, N. R. \& Satter, L. D. (1983). Journal of Animal Science 56, 943-951.

National Research Council (1985). Ruminant Nitrogen Usage. Washington DC: National Academy of Science. Poos-Floyd, M., Klopfenstein, T. \& Britton, R. A. (1985). Journal of Dairy Science 68, 829-839.

Prange, R. W., Stern, M. D., Jorgensen, N. A. \& Satter, L. D. (1984). Journal of Dairy Science 67, $2308-2314$. Prior, R. L., Huntington, G. B. \& Britton, R. A. (1981). Journal of Nutrition 111, 2212-2222.

Sniffen, C. J. \& Jacobson, D. R. (1975). Journal of Dairy Science 58, 371-385.

Spears, J. W., Hatfield, E. E. \& Clark, J. H. (1980). Journal of Animal Science 50, 750-755.

Statistical Analysis Systems (1979). Statistical Analysis Systems User Guide [J. T. Helwig and K. A. Council, editors]. Raleigh, North Carolina, USA: SAS Institute Inc.

Steinhour, W. D., Stokes, M. R., Clark, J. H., Rogers, J. A. \& Davis, C. L. (1982). British Journal of Nutrition 48, 417-431.

Stern, M. D., Hoover, H., Sniffen, C. J., Crooker, B. A. \& Knowlton, P. H. (1978). Journal of Animal Science 47, 944956.

Stock, R., Merchen, N., Klopfenstein, T. \& Poos, M. (1981). Journal of Animal Science 53, 1109-1119.

Tagari, H. \& Bergman, E. N. (1978). Journal of Nutrition 108, 790-803.

Waldo, D. R. \& Goering, H. K. (1979). Journal of Animal Science 49, 1560-1568.

Waller, J., Klopfenstein, T. \& Poos, M. (1980). Journal of Animal Science 51, 1154-1167. 